\title{
Democracia, direito e poder comunicativo: Arendt contra Marx 1
}

\author{
Yara Frateschi ${ }^{2}$ \\ yara@unicamp.br \\ Universidade Estadual de Campinas, Campinas, São Paulo, Brasil
}

resumo Intérpretes importantes costumam enfatizar o diálogo de Arendt com Heidegger quando buscam as fontes do pensamento político arendtiano. Sem recusar a relevância de Heidegger, a tese central da minha interpretação é a de que Arendt formula e responde a pergunta basilar da sua filosofia política dialogando, sobretudo, com Marx. Este artigo pretende apontar para o fato de que é recusando a teoria das classes e seus desdobramentos na utopia marxiana que ela formula a noção de natalidade, na qual fundamenta a pluralidade humana. E que é recusando a definição de homem como animal laborans que ela encontra a especificidade do homem na sua capacidade para a ação e comunicação.

palavras-chave Arendt; Marx; Trabalho; Ação; Direito

Intérpretes importantes costumam enfatizar o diálogo de Arendt com Heidegger quando buscam as fontes do pensamento político arendtiano (Cf.VILLA, 1996; BENHABIB, 2000; DUARTE, 2000). Sem recusar a relevância de Heidegger, a tese central da minha interpretação é a de que Arendt formula e responde a pergunta basilar da sua filosofia política - a respeito da característica específica e definidora do homem - dialogando, sobretudo, com Marx. Este artigo pretende apontar para o fato de que é recusando a teoria das classes e seus desdobramentos na utopia marxiana que ela formula - recolhendo inspiração em outros autores, entre eles Agostinho - a noção de natalidade, na qual fundamenta a pluralidade humana. E que é recusando a definição de homem como animal laborans 
que ela encontra a especificidade do homem na sua capacidade para a ação e comunicação ${ }^{3}$.

A pergunta pela especificidade humana foi respondida de modos diferentes ao longo da história: para os gregos, o homem era um zoon politikon; para os medievais, um animal rationale; para os modernos, um homo faber; para Marx (e em conformidade com o paradigma moderno produtivista), um animal laborans. Arendt está convencida de que esta última definição, que fazia sentido num mundo pós- revolução industrial, não é mais adequada "ao mundo em que vivemos", e que é preciso substituí-la por outra mais contemporânea: "seria mais adequado para o mundo em que vivemos definir o homem com um ser capaz de ação, pois essa capacidade parece ter se tornado o centro de todas as outras" (ARENDT, 1992, pp. 94-5). Esta é, a meu ver, a tarefa que ela assume na Condição humana e em Entre o passado e o futuro. Se é no diálogo com o idealismo de Hegel que Marx substitui a ratio pelo trabalho empreendendo uma revolução filosófica, será no diálogo com a filosofia política de Marx (principalmente com a sua filosofia da história e o seu materialismo) que Arendt substituirá o trabalho pela ação erigindo uma concepção pluralista da política e dando os primeiros passos na formulação não de um sistema - porque isso ela nunca fez nem pretendeu - e tampouco de um modelo de democracia "de acordo com qualquer idéia pré-concebida" (YOUNG-BRUEHL, 1997, p. 252), mas no sentido de estabelecer os eixos da política e os seus elementos constitutivos, aqueles que não podem ser destruídos sem que se destrua a própria política.

Arendt não é apenas crítica de Marx, que merece reconhecimento, embora não mereça adesão. Recuperando uma citação de Benjamin Constant a respeito de Rousseau, ela introduz o capítulo 3 da Condição humana, no qual assume pela primeira vez a tarefa de criticar Marx, com a seguinte escusa:

“Neste capítulo, Karl Marx será criticado. Isso é lamentável em uma época em que tantos escritores que outrora ganharam a vida pela apropriação, tácita ou explícita, da grande riqueza das idéias e intuições marxistas, decidiram tornar-se anti-marxistas profissionais (...). Ante tal dificuldade, posso evocar a declaração feita por Benjamim Constant, quando se sentiu compelido a atacar Rousseau: 'certamente evitarei a companhia dos detratores de um grande homem. Quando o acaso faz 
com que aparentemente eu esteja de acordo com eles sobre um único ponto, começo a suspeitar de mim mesmo; e, para consolar-me de parecer por um instante defender sua opinião (...) preciso repudiar e conservar distante de mim, tanto quanto eu puder, esses pretensos auxiliares"” (ARENDT, 2010, p. 97).

A grandeza de Marx, sabemos a partir de Entre o passado e futuro, reside na sua façanha filosófica. Não é o Marx sociólogo, o historiador e tampouco o economista que arranca a admiração de Arendt, mas sim o filósofo. Trata-se de um "grande pensador" porque não fugiu ao desafio de lidar com os fenômenos novos e porque se rebelou contra a tradição. A sua atitude com relação à tradição da filosofia política foi a de um rebelde consciente, que se propôs a desafiar verdades até então tidas por inquestionáveis. Com a tese segundo a qual o trabalho criou o homem, ele desafia o Deus tradicional, ao mesmo tempo em que afirma que a humanidade do homem, agora caracterizado como animal laborans e não mais como animal rationale, é resultado da sua própria atividade. Com a tese de que a violência é parteira da História, ele contradiz a idéia estabelecida de que a violência é a última ratio dos governos, transformandoa em seu elemento constituinte, a ponto de afirmar que toda esfera política é caracterizada pelo uso da violência. Por fim, a afirmação de que "os filósofos apenas interpretaram o mundo de diferentes maneiras, agora é preciso transformá-lo" afronta todo pensamento ocidental, de Platão a Hegel, para os quais a filosofia não era desse mundo. Assim sendo, a sua grandeza, assim como a de Nietzsche e Kierkgaard, cada um ao seu modo e no seu domínio, "repousa no fato de terem percebido o seu mundo como um mundo invadido por problemas e perplexidades novas com as quais nossa tradição de pensamento era incapaz de lidar" (ARENDT, 1992, p. 54). Eles são indicativos de um passado filosófico que perdeu a sua autoridade: "foram os primeiros a ousar pensar sem a orientação de nenhuma autoridade, qualquer que fosse; não obstante, bem ou mal, foram ainda influenciados pelo quadro de referencia categorial da grande tradição" (ARENDT, 1992, p. 56).

Vê-se, portanto, que o reconhecimento da importância de Marx é o reconhecimento de que ele legou aos seus sucessores filósofos uma "posição melhor" do que aquela na qual ele mesmo se encontrava. $\mathrm{Na}$ 
sua rebeldia, ele fez muito mais do que pôr Hegel "de cabeça para baixo" ou substituir "idealismo por materialismo". O seu repúdio à tradição e a Hegel está na sua recusa a admitir "que a diferença entre a vida humana e a animal seja a ratio ou o pensamento; que o homem, nas palavras de Hegel, seja essencialmente espírito" (ARENDT, 1992, p. 67). Para Marx, o homem é um ser natural dotado da faculdade de ação, que consiste no ato de trabalhar. Ainda que Arendt não possa aceitar, como veremos, essa redução da especificidade humana à atividade do trabalho, ela reconhece que, ao recusar a ratio e colocar em seu lugar algum tipo de atividade, Marx promove uma reviravolta na filosofia que vai ao cerne do problema. Ele pôs fim a toda uma tradição filosófica, invertendo a hierarquia entre pensamento e ação, entre Filosofia e Política, "quando declarou que a filosofia e sua verdade estão localizadas não fora dos assuntos dos homens e de seu mundo comum, mas precisamente neles" (ARENDT, 1992, p.44). Arendt, se vê - por causa da reviravolta que Marx fez no modo tradicional de pensar a especificidade do homem - em condições de poder corrigi-lo e de dar uma resposta melhor e mais condizente com o seu tempo à pergunta acerca da especificidade humana. É, portanto, a partir de Marx e dialogando com ele que ela se posiciona filosoficamente e estabelece os conceitos centrais da sua filosofia política.

Embora inovadoras, as três proposições-chave da filosofia política de Marx contém, cada qual, uma contradição fundamental e deixa em aberto perguntas que ele não respondeu. Se o trabalho define o homem, que atividade humana restará quando o trabalho for abolido? Se a ação violenta é a mais digna das ações humanas, como serão os homens capazes de agir de modo significativo e autêntico depois da conclusão da luta de classes e do desaparecimento do Estado? Que espécie de pensamento restará quando a filosofia tiver sido ao mesmo tempo realizada e abolida? (ARENDT, 1992, p. 54). Explorando tais contradições, nem mesmo o reconhecimento da grandiosidade de Marx impedirá Arendt de concluir que a sua rebelião tenha findado em auto-derrota (ARENDT, 1992, p.58). E apesar de não pretender engrossar o coro dos detratores e tampouco aderir ao "anticomunismo estridente", ela se vê obrigada, para recuperar o sentido da política (e redemocratizar a agenda da esquerda), a criticar Marx e o marxismo. Nota-se que, do ponto de vista do percurso intelectual de Arendt (ao menos na passagem das Origens do totalitaris- 
mo para $A$ condição humana), primeiramente ela se revela mais preocupada com a apropriação da filosofia da história de Marx pelos bolcheviques, como que buscando os elementos dessa teoria que teriam contribuído para a sua instrumentalização involuntária em nome do stalinismo. Já na Condição humana e Entre o passado e futuro, ela está mais preocupada em enfrentar não apenas o suposto 'marxismo' dos membros do partido, mas o próprio Marx. No texto que segue eu pretendo traçar as linhas gerais desses dois momentos críticos (nas Origens, a crítica do marxismo dos bolcheviques; na Condição humana, a crítica do próprio Marx), procurando mostrar que, nos dois casos, seja remexendo criticamente o marxismo dos bolcheviques ou o marxismo de Marx, ela parece encontrar, na forma de contra-argumento, as bases da sua própria filosofia política.

\section{As origens do totalitarismo}

A investigação sobre as origens históricas ou teóricas do totalitarismo, bem como dos seus efeitos, leva Arendt a constatar que o totalitarismo difere de todas as outras formas de opressão política que conhecemos, tais como o despotismo, a tirania e a ditadura (ARENDT, 2004, p. 512). Esse aspecto de absoluta novidade do regime se verifica pelo fato de que seja lá onde tenha se erigido, o totalitarismo “criou instituições políticas inteiramente novas e destruiu todas as tradições sociais, legais e políticas do país" (ARENDT, 2004, p. 512). Mais ainda, ele destruiu a própria alternativa na qual se baseia qualquer filosofia política para distinguir os regimes retos dos desviados, qual seja, a alternativa entre o governo legal e o governo ilegal, entre o poder arbitrário e o poder legítimo (ARENDT, 2004, p. 513). Entretanto, mesmo que os totalitarismos - seja o soviético ou o alemão - tenham derrubado o muro que separa a legalidade da ilegalidade, no plano teórico não operaram na mais absoluta arbitrariedade e sem a orientação de uma lei, pois alegavam “obedecer rigorosa e inequivocadamente àquelas leis da Natureza [no caso alemão] ou da Historia [no caso soviético], que sempre acreditamos serem as origens de todas as leis" (ARENDT, 2004, p. 513).

A história a que se refere Arendt aqui - mais precisamente, a filosofia da história recuperada pelos ideólogos do totalitarismo russo - é de 
matriz marxiana e vem acompanha daquela que ela considerada a mais perniciosa idéia difundida no século XX: a idéia de progresso. O que essa história (de matriz marxiana) produziu de nocivo (em mãos bolcheviques) foi a justificativa do terror. O completo desafio da legalidade foi justificado e defendido em nome da realização da "Lei da História" que conduziria à verdadeira justiça, ao progresso, à evolução. Enquanto executores dessa lei, os governantes justificam todos os seus atos, inclusive os mais assassinos. Eis o modo, enfim, pelo qual a vinculação entre história e progresso presente na filosofia da história de Marx foi usada em nome do totalitarismo. Nas palavras de Arendt: "o terror é a legalidade quando a lei é a lei do movimento de alguma força sobre humana", leia-se, a história, com H maiúsculo ${ }^{4}$.

Importa ressaltar aqui que, em As origens do totalitarismo, a critica da noção de história como progresso é vinculada à destruição da legalidade e é seguida de uma defesa contundente do governo constitucional. Se a lei da história (dos bolcheviques) justificou o desafio da legalidade, a retomada de argumentos favoráveis ao governo constitucional requer desmontar a idéia da história como progresso. Não vou enveredar aqui para a noção arendtiana de história. Importa agora, para os objetivos desse texto, notar que dessa crítica sai a idéia de que a Constituição é condição necessária da implementação de um espaço público favorável à ação e à comunicação, ou seja, à participação ativa e ampla dos cidadãos na política, que só se realizam na medida em que os cidadãos criam "espaços de liberdade" que lhes permitam tornar público o seu ponto de vista e gerar, por meio da comunicação e da persuasão, soluções compartilhadas. Mas esses espaços só existem enquanto o poder (compartilhado e construído pelos cidadãos) não for usurpado pela violência. A defesa da Constituição é uma reação aos regimes tirânicos, ditatoriais e totalitários e visa reforçar o elemento jurídico indispensável da política. A constituição e as instituições que zelam por ela dão estabilidade ao corpo político, sem a qual a participação ativa dos cidadãos e a assimilação do novo no mundo não seriam possíveis. Está aqui, em As Origens, o germe da noção de poder comunicativo, bem como de uma idéia que ela desenvolverá na Condição humana e em Da revolução, ao mostrar que deve haver um equilíbrio entre natalidade (novidade) e permanência para que o espaço publico possa comportar a aparição de novos atores e suas demandas ${ }^{5}$. Isso significa que 
as leis desempenham um papel fundamental, não exatamente de oprimir e constranger, mas de erigir as fronteiras entre as pessoas, sem as quais elas não podem se relacionar e tampouco se comunicar:

"No governo constitucional, as leis positivas destinam-se a erigir fronteiras e a estabelecer canais de comunicação entre os homens cuja comunidade é freqüentemente posta em perigo pelos novos homens que nela nascem (...). A estabilidade das leis corresponde a um constante movimento de todas as coisas, um movimento que jamais pode cessar enquanto nascem e morrem. As leis circunscrevem cada novo começo e ao mesmo tempo asseguram a sua liberdade de movimento, a potencialidade de algo inteiramente novo e imprevisível" (ARENDT, 2004, p.517).

Isso não significa, obviamente, que o estado constitucional seja condição suficiente da liberdade, pois a liberdade exige ação política e participação ativa. Mas como a liberdade não vigora num ambiente onde as fronteiras da lei foram abolidas, o estado constitucional é sim condição necessária da vida política: "abolir as cercas da lei entre os homens - como faz a tirania - significa tirar dos homens os seus direitos e destruir a liberdade como realidade política viva; pois o espaço entre os homens delimitado pela lei é o espaço vital da liberdade" (ARENDT, 2004, p. 518). Com isso, Arendt marca posição em relação à desconfiança profunda nutrida pelo pensamento de esquerda desde Marx a respeito do elemento jurídico da política: para ela, o direito é condição necessária da liberdade, não sendo congenitamente violento e opressivo. Não que não se possa violentar o direito - quem viveu a transição da República de Weimar para o nazismo sabe que sim -, mas a violência deriva do uso e não da natureza do direito.

Não é só da abolição efetiva das fronteiras da lei pelos governos totalitários que Arendt se ocupa em "Ideologia e Terror" (1953), há também o inicio de um diálogo com a matriz ideológica que teria animado a sua vertente pretensamente de esquerda: sem qualquer referencia explicita aos textos de $A$ ideologia alemã ou $A$ questão judaica, ela está recusando, nas entrelinhas, que o direito seja mera ideologia ou superestrutura que visa manter a dominação de uma classe sobre outra. E, assim, nesse texto, ela lança as bases da sua filosofia futura. Anti-marxista quanto ao fator jurídi- 
co, ela já defende aqui que o direito é condição da liberdade; anti-liberal no que tange à noção de liberdade, ela pensa a liberdade não como confinamento no privado mas como exercício da comunicação. Mais tarde, ao coroar esse anti-marxismo anti-liberal (que reúne o elemento jurídico e institucional com a liberdade positiva) ela dirá que "o verdadeiro conteúdo da liberdade significa participação nas coisas públicas ou admissão no mundo público" (ARENDT, 1990, p. 26). Nesse sentido, a distinção entre poder (participativo e comunicativo) e violência é crucial no pensamento político de Arendt e tem, sobretudo, a função de detectar o que diferencia as repúblicas livres das ditaduras e dos totalitarismos.Vemos, assim, como da investigação sobre as origens do totalitarismo - e das ideologias que o teriam animado - Arendt extrai os elementos que o distinguem das democracias e que são pelo menos dois: constituição (direito) e cidadania participativa (poder comunicativo).

\section{A condição humana}

Se, em As origens, Arendt recupera criticamente a filosofia da história de Marx enfatizando a noção de história como progresso e a sua apropriação pelos bolcheviques, em $A$ condição humana a ênfase recai sobre a concepção da história como luta econômica entre as classes. Na primeira obra, Marx figurava como ideólogo involuntário do bolchevismo, agora Arendt o encara como aquele que "conceitualizou e transformou em programa as premissas subjacentes a duzentos anos de modernidade": o que a interessa em $A$ condição humana é justamente esse programa. Segundo ela, o elemento que Marx extrai da modernidade e sobre o qual constrói o programa socialista é a definição de homem como animal laborans, a partir da qual ele operaria um duplo reducionismo que redundaria, finalmente, na abolição da política. Explica-se: em primeiro lugar, Marx define o homem como um animal que trabalha, definição que carrega o confinamento do homem à sua capacidade produtiva; tendo feito isso, ele substitui a multiplicidade de interesses individuais e pessoais por interesses de grupo ou de classes, que são, por sua vez, reduzidas a duas classes principais: a de capitalistas e a de trabalhadores (ARENDT, 2010 p. 512). Parece-me que o ponto nevrálgico da discordância com Marx está 
exposto aqui: para Arendt, ele é reducionista porque não distingue interesse pessoal de interesse de classe, ou seja, porque dilui o indivíduo sem que este tenha como reivindicar qualquer identidade que não seja a identidade da classe a qual pertence. Ocorre que a diluição do individuo na classe ou na sociedade socializada pós-revolução sustenta a ficção de uma harmonia que aniquila a possibilidade mesma da construção de um mundo comum, que é um mundo comum entre indivíduos distintos e que vêem o mundo de perspectivas distintas, mesmo que possam se reunir em grupos de interesses. A esfera pública, em contrapartida, é um mundo comum na medida em que nos reúne uns com os outros ao mesmo tempo em que evita que colidamos uns com outros (ARENDT, 2010, p. 61), mas nos reúne na nossa pluralidade, que não resiste à ficção comunista de Marx: "o mundo comum acaba quando é visto somente sob um aspecto e só se lhe permite apresentar-se em uma perspectiva" (ARENDT, 2010, p.71). E isso ocorre, em graus diferentes, no totalitarismo e na sociedade de massas, tanto quanto ocorreria na humanidade socializada de Marx, devido à eliminação da lacuna entre a existência individual e a existência social do homem (ARENDT, 2010, p.110. nota 21): a humanidade socializada de Marx consiste em "espécimes sem mundo da espécie humana" (ARENDT, 2010, p.146).

Cumpre observar que essa crítica à teoria das classes não é feita por Arendt pela admissão do ponto de vista do liberalismo. Arendt não compra o argumento liberal de que a mão invisível permitiria resolver a contradição entre interesse individual e coletivo ao mesmo tempo em que preservaria a integridade da multiplicidade de interesses e preferências individuais. Parece que, para ela, a mão invisível denuncia que o liberalismo - como o marxismo, ainda que com o sinal trocado - pressupõe, contra essa multiplicidade, a existência de um interesse único da sociedade como um todo. Nesse sentido, Marx e A. Smith, cada um ao seu modo, compartilham o ideal de uma sociedade harmônica e, portanto, profundamente anti-política. Com a diferença - apenas de grau - de que o homem socializado de Marx é um ser ainda menos ativo do que o homem econômico da economia liberal (ARENDT, 2010, p. 51).

Em resumo, do mesmo modo que Arendt denuncia o reducionismo da teoria das classes ela também questiona a solução do conflito pela via revolucionária e pela instauração do socialismo, do qual, para ela, não 


\section{2}

resultaria, como teria desejado Marx, o estabelecimento de um mundo compartilhado e do reino da liberdade. Se os homens estão apartados de si mesmos e dos outros no capitalismo, estarão também na sociedade socializada, pois esta destrói a vida privada e, ao destruí-la, desaparece com as fronteiras necessárias ao estabelecimento da esfera pública. Para Arendt, a socialização do processo de produção material seria acompanhada da substituição do indivíduo pela sociedade, "pela espécie humana coletiva", o que não acarreta apenas, como desejou Marx, na abolição do governo, mas na abolição da própria política. Daí ela dizer que, em Marx, o ideal socialista de uma condição final da humanidade sem Estado significa sem política. E ela conclui:"isso é pavoroso" (ARENDT, 2007, p. 85).

Mas Marx não errou completamente em suas previsões, infere Arendt com ácida ironia. Pelo contrário, ele mais acertou do que errou, ainda que pelas causas equivocadas e com indevido jubilo. Efetivamente, na sociedade de massas ocorre a uniformização dos pontos de vista, pois nela todos passam "subitamente a se comportar como se fossem membros de uma grande família, cada um a multiplicar e prolongar a perspectiva do vizinho" (ARENDT, 2010, p. 71). Também na sociedade de massas ocorre o definhamento do Estado, que cedeu lugar à mera administração nas condições de um desenvolvimento desenfreado das "forças produtivas da sociedade". Logo, a sociedade de Marx, sem classe e sem Estado, não é utópica: ela pode se realizar, e se realizou, ainda que não tenha sido precedida por uma revolução como ele imaginou e não tenha sido sucedida da conquista da liberdade, como ele desejou (ARENDT, 2010, 162, nota 82). O único elemento estritamente utópico de Marx é, para ela, a emancipação do homem em relação ao trabalho e a conquista subseqüente da liberdade.Voltarei a esse ponto mais adiante.

Retomando o fio argumentativo de $A$ condição humana, notamos que, para responder à pergunta acerca da qualidade ou característica especificamente humana (que é a pergunta em torno da qual ela constrói todo o argumento do livro) e recuperar a multiplicidade de perspectivas negada pela teoria marxiana das classes, Arendt se vê obrigada a repensar as atividades propriamente humanas, que não se reduzem ao trabalho, mas são de três ordens distintas, ainda que complementares: o trabalho, a obra e a ação. Parece-me que Arendt chega a essa distinção, que é basilar da sua filosofia, reagindo à definição marxiana do homem como animal laborans 
e à concepção materialista da história. Contra a idéia exposta em $A$ ideologia alemã de que o que os indivíduos são "coincide com a sua produção, isto é, tanto com o que eles produzem quanto com a maneira como produzem" (MARX, 2002, p.11), A condição humana defende uma diferenciação entre o trabalho e a obra - o primeiro ligado à satisfação das necessidades vitais e o segundo à construção de um mundo artificial no qual os homens habitam - e, mais importante ainda, entre essas duas atividades e a ação:

"Com a expressão vita activa, pretendo designar três atividades humanas fundamentais: trabalho, obra e ação. São fundamentais porque a cada uma delas corresponde uma das condições básicas sob as quais a vida foi dada ao homem na Terra.

O trabalho é a atividade que corresponde ao processo biológico do corpo humano, cujo crescimento espontâneo, metabolismo e resultante declínio estão ligados às necessidades vitais produzidas e fornecidas ao processo vital pelo trabalho. A condição humana do trabalho é a própria vida.

A obra é a atividade correspondente à não-naturalidade na existência humana, que não está engastada no sempre-recorrente ciclo vital da espécie (...). A obra proporciona um mundo artificial de coisas, nitidamente diferente de qualquer ambiente natural. Dentro de suas fronteiras é abrigada cada vida individual, embora esse mundo se destine a sobreviver e a transcender todas elas. A condição humana da obra é a mundanidade.

A ação, única atividade que ocorre diretamente entre os homens, sem a mediação das coisas ou da matéria, corresponde à condição humana da pluralidade, ao fato de que os homens, e não o Homem, vivem na Terra e habitam o mundo. Embora todos os aspectos da condição humana tenham alguma relação com a política, essa pluralidade é especificamente a condição - não apenas a conditio sine que non, mas a conditio per quam - de toda vida política (ARENDT, 2010, p. 8).

Não pretendo explorar exaustivamente a diferença entre trabalho e obra bem como o modo, por vezes rigorista e nem sempre muito convincente, pelo qual Arendt aborda essa distinção em $A$ condição humana. $\mathrm{O}$ que está em seu horizonte é recuperar a distinção, perdida no mundo 


\section{4}

moderno, entre a esfera privada e a esfera pública e, ao mesmo tempo, recusar a instrumentalização da política pela sociedade e a sua contaminação provocada, sobretudo, pela elevação de questões sociais (econômicas) ao espaço público ${ }^{6}$. Para tanto, ela cria uma diferenciação conceitual entre vida e mundo, da qual deriva uma primeira e mais elementar distinção entre as atividades do trabalho (correspondente à manutenção da vida) e da obra (responsável pela criação de um mundo artificial que resiste ao ciclo da vida), e entre estas e a ação (condição da vida política, ou seja, de relações humanas não mediadas pelas coisas e pela matéria). No que diz respeito à diferenciação entre trabalho e obra, importa reter aqui o contraste entre a permanência dos objetos produzidos pela obra e a não durabilidade dos produtos do trabalho (ARENDT, 2010, p. 107). Novamente é Marx quem a orienta, ainda que na contramão: fascinado pela produtividade sem precedentes da humanidade, ele tende a privilegiar o trabalho e a considerá-lo como obra, bem como tende a "falar do animal laborans em termos muito mais adequados ao homo faber" (ARENDT, 2010, p. 107). Arendt não aceita essa atitude de Marx (e da modernidade em geral) em relação ao trabalho porque ela revela um ponto de vista que glorifica indevidamente o trabalho, confundindo-o com uma atividade criativa, mas que, no fundo, leva em conta apenas o processo vital do gênero humano (ARENDT, 2010, p. 109). Ou seja, um ponto de vista que privilegia não a construção de um mundo durável ou de um mundo compartilhado, mas o ciclo da vida biológica e da natureza, e que leva Marx a concluir que os homens se distinguem dos animais quando começam a produzir os meios de sua subsistência (ARENDT, 2010, p. 112). Em contrapartida, Arendt insiste que não se compreende a especificidade humana a partir desse "naturalismo" ou desse "fisiologismo", que fez Marx se convencer do absurdo de que "Milton produziu o Paraíso Perdido pela mesma razão que o bicho-daseda produz seda" (ARENDT, 2010, p. 123, nota 36).

Ao privilegiar o trabalho, que é uma atividade destinada à supressão de necessidades vitais elementares, Marx faz dos homens seres destinados a suprimi-las ${ }^{7}$. Arendt entende que, desse modo, ele não apenas retira do homem a capacidade de criar um mundo permanente - o que no limite significa transformar os homens em consumidores constantes - como também a capacidade de agir em conjunto. Um outro fator importante é 
que a diluição da diferenciação entre essas atividades é extremamente nociva porque perde de vista o fato de que o trabalho - que visa satisfazer necessidades elementares do corpo - não exige qualificação individual: é apenas na obra que os indivíduos podem se distinguir uns dos outros. Tanto é assim, diz Arendt, que o próprio Marx previu - acertadamente, mais uma vez - que a divisão do trabalho tende a abolir o trabalho qualificado (ARENDT, 2010, p. 110). Mas a despeito de todas as questões que essa diferenciação entre as duas atividades pode suscitar, entendo que a sua função principal é atacar o "fisiologismo" de Marx (que alimenta o seu materialismo) e recuperar a dignidade da política, que desaparece quando se reduz o homem a um animal laborans: para sermos capazes de ação política não podemos estar imersos no movimento cíclico da natureza (fisiologismo) ou sermos apenas consumidores constantes, mas é preciso (1) que sejamos capazes e estejamos imbuídos da tarefa de criar um mundo com alguma permanência e também (2) que sejamos capazes de nos relacionarmos uns com os outros a partir da diversidade de perspectivas individuais. No que diz respeito à primeira exigência feita por Arendt, o que está em pauta é a constatação de que "se o mundo deve conter um espaço publico, não pode ser construído apenas para uma geração e planejado somente para os que estão vivos, mas tem que transcender a duração da vida de homens mortais" (ARENDT, 2010, p. 67). Essa transcendência, possibilitada pela permanência e pela publicidade, é necessária para que os homens ingressem na esfera pública preocupados com as gerações passadas e também, principalmente, com as vindouras. $\mathrm{O}$ ator político tem essa responsabilidade, que o animal laborans não tem, de levar em conta o que ele quer deixar para as outras gerações ${ }^{8}$. No que tange à segunda exigência, o que Arendt quer, mais uma vez contra Marx, é ressaltar que a realidade do mundo comum "depende da presença simultânea de inúmeros aspectos e perspectivas nos quais o mundo se apresenta e para os quais nenhuma medida ou denominador comum pode ser concebida" (ARENDT, 2010, p. 70). A medida será encontrada justamente na política, mediante a construção de acordos.

Enfim, o que Marx não viu, com a sua concepção materialista, é que a política depende de uma pluralidade de interesses que não se confinam a interesses materiais e que, portanto, para ser exercida, depende de haver um tipo de atividade que "se exerce diretamente entre os homens sem a 


\section{6}

mediação das coisas ou da matéria". O erro do materialismo em política é ignorar "a inevitabilidade com que os homens se desvelam como sujeitos, como pessoas distintas e singulares" (ARENDT, 2010, p.229). Parece-me, portanto, evidente que a definição arendtiana de ação é uma reação à afirmação - de Marx e Engels em $A$ ideologia alemã - segundo a qual o que os homens são depende das condições materiais de produção. Para fazer reviver a multiplicidade de interesses, Arendt precisa, então, negar o materialismo e também o economicismo, que ela julga dominar não apenas o pensamento liberal, mas também o de Marx e dos marxistas. Em outras palavras, para recuperar a dignidade da política, restabelecendo a sua especificidade em relação à racionalidade instrumental e econômica, é preciso garantir que haja um espaço para a relação interhumana não determinado pela racionalidade instrumental e econômica ("sem mediação das coisas ou da matéria"), sendo que as relações políticas se dão justamente nesse espaço. Nesse sentido, entendo que devemos ler $A$ condição humana como uma obra que tem como um dos seus objetivos principais negar a teoria marxiana das classes, bem como a noção de história como luta econômica entre as classes, para fazer emergir a pluralidade que essa mesma teoria teria escondido.

\section{A contradição de Marx}

A crítica à vitória do animal laborans empreendida por Arendt vem acompanhada da crítica ao triunfo da razão econômica, que ela percebe ter penetrado todos os domínios e impedido a distinção das atividades humanas, reduzindo-as a uma só: o trabalho. Essa definição de homem como animal laborans, leva Marx a fincar pé na modernidade que ele pretende superar e o leva a uma contradição que marca todo o seu projeto: ele define o homem como um animal que trabalha para depois abolir, no momento pós-revolucionário, a sua característica definidora. Sobre a contradição que permearia todo o pensamento de Marx, diz Arendt:

"Mas estes são pontos secundários quando comparados à contradição fundamental que eiva, como um estigma, todo o pensamento de Marx, e que está presente tanto no terceiro volume de O Capital quanto nas obras do jovem Marx. A atitude de Marx em relação ao trabalho, em 
relação ao próprio foco do seu pensamento, sempre foi equívoca. Embora o trabalho fosse uma 'eterna necessidade imposta pela natureza' e a mais humana e produtiva das atividades do homem', a revolução, segundo Marx, não se destinava a emancipar as classes trabalhadoras, mas a emancipar o homem do trabalho; somente quando o trabalho é abolido pode o 'reino da liberdade' suplantar o 'reino da necessidade'. Pois 'o reino da liberdade começa onde termina o trabalho imposto pela necessidade e pela utilidade exterior', onde termina o 'império das necessidades físicas imediatas" (ARENDT, 2010, p.116).

O problema é Marx fazer do homem um animal laborans e, ao mesmo tempo, levá-lo a uma sociedade "na qual este poder, o maior e mais humano de todos, já não é necessário” (ARENDT, 2010, p.117). Com uma tal definição, Marx não tem o que fazer com os homens quando o trabalho for abolido: não é a liberdade que eles conquistarão porque animais que laboram obviamente não se tornam livres com a abolição do labor (por isso ela diz que os homens socializados de Marx estariam destinados aos hobbies.). Em suma, não dá para definir o homem como animal laborans e prometer a liberdade na sociedade socializada: se o homem é um animal que trabalha, a abolição do trabalho não só não pode significar a conquista da liberdade como significará também a abolição da própria característica definidora do homem. Arendt conduz a sua crítica de modo a identificar os homens socializados de Marx com aqueles que perderiam justamente aquilo que os faz homens e os diferenciam dos animais, seriam homens esvaziados da sua humanidade, praticantes de atividades destituídas de função ou de significado: “'socializados' e libertos do trabalho, os homens gozariam essa liberdade em atividades estritamente privadas e essencialmente isoladas do mundo que hoje chamamos "hobbies"" (ARENDT, 2010, p.145) ${ }^{9}$. Daí o retrato nada edificante que ela desenha da sociedade comunista:

"na sociedade comunista ou socialista todas as profissões se tornariam uma espécie de hobby: não haveria pintores, mas apenas pessoas que, entre outras coisas, passam parte do tempo pintando; ou seja, pessoas que 'hoje fazem uma coisa, amanhã fazem outra, que caçam pela manhã, pescam à tarde, criam gado ao anoitecer, são críticos após o 
jantar, a seu bel-prazer, sem por isso jamais chegarem a ser caçadores, pintores, pescadores pastores ou críticos"” (ARENDT, 2010, p. 145, nota 65$)$.

Para corrigir esse erro e não permitir a rendição da liberdade à necessidade, faz-se necessário operar uma separação "inteiramente não marxista" entre economia e política (ou entre liberdade e necessidade) para que, assim, o discurso possa aparecer como característica definidora do homem e da própria política.

\section{Marx funcionalista}

Como vimos, para Arendt, a idéia da história como luta econômica entre as classes é reducionista porque confina o político ao econômico. Isso não significa, entretanto, que ela não reconheça a acuidade de alguns dos conceitos e explicações econômicas de Marx, a quem ela muitas vezes se refere como leal e integro na descrição dos fenômenos (Cf. ARENDT, 2004, p. 20; ARENDT, 2010, 129). Para ela, por exemplo, a noção de força de trabalho é o elemento mais original e revolucionário de Marx na medida em que revela que a produtividade do trabalho reside na força humana "cujo vigor não se esgota depois que ela produz os meios de sua subsistência e sobrevivência, mas é capaz de produzir um excedente, isto é, mais do que o necessário à sua própria reprodução" (ARENDT, 2010, p.108). Outras tantas vezes ela recorre a Marx para explicar, por exemplo, o funcionamento do mercado de trocas (ARENDT, 2010, p.202), a degradação dos homens em mercadorias (ARENDT, 2010, p.203), a produção do valor (ARENDT, 2010, p.206) ou ainda a acumulação primitiva de capital (ARENDT, 2010, p.178).Vemos, portanto, que o mesmo Marx - autor de uma filosofia da história e de um programa socialista que ela critica severamente - não deixa de ser, concomitantemente, uma fonte importante quando se trata de compreender a formação e o modo de funcionamento do capitalismo, o que para ela é indispensável para que se entenda a vitória da razão econômica na modernidade (que Marx foi capaz de desvendar, mas não de superar) ${ }^{10}$. 
Ainda assim, Marx não é a única e tampouco a melhor fonte nesse assunto e as suas hipóteses podem até dar conta dos primeiros estágios do capitalismo, mas muitas não sobrevivem às suas transformações (ARENDT, 1990, cap. 2). Ademais, e principalmente, também ele sucumbiu à necessidade, elevando a questão social ao primeiro plano e transformando o objetivo da revolução não na conquista da liberdade, mas na abundância (ARENDT, 1990, p. 51). E a essa submissão do político ao econômico soma-se a sua ambição em elevar a sua 'ciência' ao nível da ciência natural: "A luta de classes: para Marx essa fórmula parecia desvendar todos os segredos da história, exatamente como a lei da gravidade parecia desvendar todos os segredos da natureza" (ARENDT, 1992, p. 115). Pior ainda, ele supôs que com a revolução "a apropriação coletiva faria coincidir fins individuais e fins coletivos, interesses de cada um e interesses de todos" (GORZ, 2003, p. 45). No âmago disso tudo há um profundo desprezo pela democracia, pelo processo democrático participativo de tomada de decisão, pela própria política, que, quando muito, é um meio para a eliminação do domínio de classe, que com ela se extingue ${ }^{11}$. A glorificação da violência contida na tese segundo a qual "a violência é parteira de toda velha sociedade prenhe de uma nova" é, segundo Arendt, a prova da hostilidade de Marx ao discurso e à democracia ${ }^{12}$.

No enfrentamento com Marx é inevitável perceber que o alvo de Arendt é o funcionalismo que, para ela, caracteriza o seu modo de pensar e também o modo de pensar daqueles que o seguem. Foi ele quem "superpôs a Lei da História à Política, findando por perder o significado de ambas - da ação, não menos que do pensamento, e da Política não menos que da Filosofia - ao insistir que eram meras funções da sociedade e da história" (ARENDT, 1992, p. 57). Esse funcionalismo, tão reducionista quanto a teoria das classes, contaminou os ícones da esquerda e empobreceu as ciências sociais. O seu resultado é, mais uma vez, a derrocada da política: Marx colocou "a mais baixa das atividades humanas, a atividade do trabalho, no mais alto grau. A ação, agora, parecia não ser mais do que uma "função" das relações de produção da humanidade erigidas pelo trabalho".

Arendt recusa esse funcionalismo assim como recusa a "superstição" implicada no diagnóstico daqueles que só enxergam a ruína do nosso tempo (ARENDT, 2004, p.12). Nos dois casos, o que se perde é a possi- 
bilidade de ver a realidade sem preconceitos. Mesmo com toda a violência e a destruição que o século XX produziu, ela pondera:

"Mas permanece também a verdade de que todo fim na história constitui necessariamente um novo começo; esse começo é a promessa, a única 'mensagem' que o fim pode produzir. O começo, antes de tornar-se evento histórico, é a suprema capacidade do homem; politicamente, equivale à liberdade do homem. Initium ut esset homo creatus est - 'o homem foi criado para que houvesse um começo', disse Agostinho. Cada novo nascimento garante esse começo; ele é, na verdade, cada um de nós" (ARENDT, 2004, p. 531).

Com a noção de natalidade, que traduz a possibilidade do novo no mundo, Arendt reage - possivelmente também ao diagnóstico de Adorno e Horkheimer na Dialética do esclarecimento - sem pessimismo ou otimismo temerário, mas acenando para os possíveis espaços de liberdade que só a ação política pode abrir ${ }^{13}$. Se ela recusa a ideologia do progresso, tampouco aceita a que apregoa a ruína indefinidamente. Ao encerrar a Condição humana, apesar de extremamente crítica com relação à sociedade contemporânea, Arendt parece discordar do diagnóstico segundo o qual a humanidade está "se afundando numa nova espécie de barbárie" (ADORNO \& HORKHEIMER, 1985, p. 12). A despeito da vitória do animal laborans, "isso não significa que o homem moderno tenha perdido suas capacidades ou esteja a ponto de perdê-las": "Digam o que disserem a sociologia, a psicologia e a antropologia acerca do 'animal social', os homens persistem em produzir, fabricar e construir (...). Analogamente, retemos ainda a capacidade de agir (...). Finalmente, a capacidade de pensar (...) ainda é possível e sem dúvida está presente onde quer que os homens vivam em condições de liberdade política" (ARENDT, 2010, pp. 404-6).

Sem otimismo ou pessimismo "supersticioso", ela reconhece, ainda no começo da década de 50, os ganhos do movimento operário e feminino. Se, por um lado, ela acusa que nenhuma forma moderna de Estado foi capaz de concretizar mecanismos que possibilitam plenamente o agir político - ou seja, de garantir a participação intensa e direta no governo que ela identifica com o ser-livre, com a liberdade - ainda assim, por outro lado, ela reconhece "que o conteúdo e extensão da liberdade 
tenham se modificado de forma bastante extraordinária" (ARENDT, 2007, p. 75). Um sinal disso, uma evidência desse incremento da liberdade na contemporaneidade, diz ela, foi a emancipação feminina e operária: "só o fato da emancipação das mulheres e da classe operária, quer dizer de grupos de homens [e mulheres] que nunca antes podiam mostrar-se na vida pública, dá um rosto radicalmente novo a todas as questões políticas" (ARENDT, 2007, p. 76). A emancipação das mulheres e operários é uma concretização da entrada do novo no mundo e, nesse sentido, tem um "aspecto revolucionário". E onde ela ocorre? Ocorre em um contexto em que a política é vista como meio para a conservação da vida e da sociedade e em que tudo se faz para limitar a coisa pública. No entanto, nesse mesmo contexto, é possível buscar eliminar a violência e a dominação do homem sobre o homem [e sobre a mulher] e é aí que passa a haver lugar para a emancipação: "a emancipação da classe operária e das mulheres, quer dizer, de duas categorias que em toda história pré-moderna foram submetidas à força, indica, da maneira mais clara o ponto culminante desse desenvolvimento" (ARENDT, 2007, p. 80).

Em 1970, estimulada a refletir sobre a posição de intelectuais marxistas que detectavam na experiência tcheca e húngara a possibilidade de regeneração do socialismo, Arendt desbasta a diferença - por estes repisada - entre capitalismo e socialismo: são gêmeos, "cada um usando um chapéu diferente" (ARENDT, 1973, p. 184). Todas as nossas experiências, "e não teorias e ideologias, nos contam que o processo de expropriação, que começou com a ascensão do capitalismo, não cessa com a expropriação dos meios de produção; só instituições legais e políticas independentes das forças econômicas e seu automatismo podem controlar e equilibrar as monstruosas potencialidades inerentes a esse processo" (ARENDT, 1973, p. 183) ${ }^{14}$. Em suma, uma vez que tanto o capitalismo quanto o socialismo promoveram expropriação, um não é exatamente uma alternativa ao outro. A questão urgente, o problema a ser resolvido, não é, então, "como expropriar os expropriadores", mas como fazer com que as massas, "despojadas pela sociedade industrial nos sistemas capitalista e socialista, possam recuperar a propriedade" (ARENDT, 1973, p. 184). Descrente da posse coletiva das fábricas e severamente critica da abolição da propriedade privada, Arendt volta a comemorar os ganhos do movimento operário no plano jurídico, transformando o respeito aos 
direitos dos trabalhadores em um critério pelo qual se pode distinguir os países mais ou menos democráticos ${ }^{15}$. Outro critério é a liberdade de divergir: os direitos civis e as garantias legais são as condições "para ser livre, para falar, escrever e imprimir o que se quiser" (ARENDT, 1973, p. 187). Com esses critérios, ela estabelece que a democracia exige, ao menos, espaços públicos que permitam o exercício da comunicação e a formação racional da opinião, bem como a salvaguarda legal das conquistas efetuadas e concretizadas em direitos.

Voltando ao Marx, importa reter aqui que Arendt não pretende apenas desmentir a sua previsão segundo a qual a contradição entre forças produtivas e relações de produção acarretaria no acirramento de um conflito e de um antagonismo que faria com que o proletariado configurado então como classe universal - fizesse a revolução, tomasse coletivamente os meios de produção e instaurasse o reino da liberdade. Não se trata de recusar a filosofia da história porque a história a desmentiu, mas porque ela antagoniza com a possibilidade mesma da instauração de um espaço publico no qual vige a pluralidade e no qual as pessoas possam aparecer trazendo demandas distintas e legítimas a serem transformadas em direitos. Numa palavra, o pluralismo de Arendt é irreconciliável com a idéia do proletariado como classe universal ou portador de um interesse universalizável.

Neste texto procurei mostrar que, criticando Marx, Arendt estabelece que os elementos constitutivos da política democrática são a ação participativa e comunicativa, bem como o direito que garante ao mesmo tempo a estabilidade e a entrada do novo no mundo compartilhado. Como observa muito bem Habermas a respeito de Arendt, o poder político - que é poder comunicativo - configura-se como "força autorizadora que se manifesta na criação do direito legítimo e na fundação das instituições" (HABERMAS, 2003, vol. I, p. 187). Trata-se de um tipo de poder que só pode se formar em condições de liberdade política, onde todos podem argumentar a favor das suas opiniões, sendo essa a condição necessária para a formação racional da vontade, para a conquista de acordos e, finalmente, de direitos. 
Certamente, há uma série de lacunas no pensamento político arendtiano, sendo que as mais relevantes derivam da sua restritiva concepção de espaço público (desenvolvida em textos como $A$ condição humana e Sobre a revolução) e do desequilíbrio entre a atenção que ela dá ao poder comunicativo em comparação com o poder coercitivo ou administrativo ${ }^{16}$. Entretanto, apesar das lacunas, Arendt fornece, com a sua noção de poder comunicativo (elaborada em reação à definição de homem como animal que trabalha), arsenal conceitual para a formulação de novos modelos de democracia: esta noção está na base das teorias da democracia mais importantes e pertinentes da contemporaneidade ${ }^{17}$.

1 Uma primeira versão deste texto foi apresentada no Colóquio Internacional "Apropriaciones Contemporaneas", que aconteceu em 2009 na UNGS (Buenos Aires), e publicada nos anais do evento com o título: "H. Arendt: nem com nem contra Marx". Esta segunda versão incorpora críticas e sugestões dos colegas do Grupo de Filosofia Alemã, ainda que não apresente nenhuma grande alteração no argumento central daquele primeiro texto (ainda não publicado em periódico). A alteração mais relevante está na tônica, que agora recai mais sobre as críticas que Arendt endereça a Marx do que na suposta ambigüidade da sua posição em relação ao autor de $O$ capital. Agradeço aos membros do grupo e principalmente a Ricardo Terra, Bruno Nadai, Fernando Costa Mattos, Rurion Soares Melo e Marisa Lopes.

2 Professora de Ética e Filosofia Política do Departamento de Filosofia da UNICAMP.

3 Depois de terminar As origens do totalitarismo, Arendt planejou escrever um livro sobre Marx e o marxismo. Como mostra E. Young-Bruehl, tudo o que ela escreveu entre 1952 e 1956 estava voltado para este projeto, ainda que o livro jamais tenha sido publicado. O projeto se dividia em três etapas: na primeira, ela pretendia analisar a definição do homem como animal laborans e o conceito de história como feita pelo homem. Na segunda, ela pretendia analisar o marxismo europeu e o socialismo entre 1870 e 1917. Na terceira e última parte, ela deveria investigar os elementos totalitários do marxismo (YOUNG-BRUEHL, 1997, p. 254). Mesmo não tendo finalizado o livro, as partes realizadas foram integradas aos seus outros livros, como o ensaio sobre Marx e a tradição integrado a Entre o passado e o futuro e o texto sobre o trabalho em A condição humana. A importância decisiva de Marx para Arendt e o modo como acabou determinando o seu percurso intelectual se fazem ver pelo fato de que no período entre 1958 e 1962, ela "entregou três livros para publicação, A condição humana, Entre o passado e o futuro e Sobre a revolução, que haviam brotado do trabalho original sobre o marxismo" (Idem, p. 256).

4 Cf. ARENDT, 2004, p.517. Isso não significa, que Arendt atribua a Marx qualquer responsabilidade pelo totalitarismo soviético, obviamente, mas apenas que a sua teoria foi instrumentalizada servindo de ideologia para justificar o terror. Como ela diz em Entre o passado $e$ o futuro, "responsabilizar os pensadores da idade moderna, especialmente os rebeldes contra a 
tradição do século XIX, pela estrutura e pelas condições do século XX é ainda mais perigoso que injusto" (ARENDT, 1992, p. 54).

5 Desenvolvi essa questão em FRATESCHI,Y. "Participação e liberdade política em Hannah Arendt" Cadernos de Filosofia Alemã, n. 10, 2007, p. 84.

${ }^{6}$ Habermas e S. Benhabib criticam Arendt por ter desenhado um modelo muito restritivo de espaço público. Para Habermas, que se assume em débito com a noção arendtiana de poder comunicativo, Arendt acaba perdendo força e adequação às sociedades contemporâneas quando se contrapõe integralmente aos elementos estratégicos do poder e não aceita a intrusão de questões econômicas e sociais na esfera pública (HABERMAS, 1997). S. Benhabib, que considera Arendt "a pensadora mais importante" do século vinte (BENHABIB, 2006, p. 106), também nota as dificuldades nas quais Arendt acaba por se enredar ao promover uma separação tão rígida entre o publico e o privado, o econômico e o político. Essa rigidez a impede de admitir que a atividade do trabalho, por exemplo, pode converter-se (e frequentemente se converte na modernidade) em questão própria do espaço público quando vista do ponto de vista das relações assimétricas de poder que a governa (BENHABIB, 2006, p. 111). Mas como Arendt a relega, assim como quase todas as questões econômicas, ao âmbito privado, acaba passando por alto do fato de que estas atividades, "na medida em que se baseiam em relações de poder, também podem converter-se em motivos de disputa pública” (BENHABIB, 2006, p. 112). Habermas e Benhabib têm razão ao acusar essa concepção restritiva de espaço público e apontar que, com ela, Arendt dificilmente responde à complexidade do espaço público moderno. Entretanto, nem mesmo Arendt mantém a ferro e fogo essa rígida separação, que aparece, principalmente em $A$ condição humana e em Sobre a revolução. Em outros momentos, quando ela comemora, por exemplo, a emancipação operária e feminina (Cf. ARENDT, 2007, fragmento 3) ou as conquistas em termos de direitos do movimento trabalhista (cf. Entrevista de 1970 publicada em Crises da república), as suas análises admitem, sem quaisquer reticências, a inter-relação entre os dois domínios e o reconhecimento de que questões tradicionalmente relegadas ao âmbito privado, quando levadas ao espaço público, ganham dimensão emancipatória traduzida em ganhos jurídicos. É inevitável constatar a ambigüidade de Arendt nesse aspecto e eu não pretendo resolve-la aqui. Por ora, apenas aponto para outros textos, como os supracitados, nos quais ela não blinda a política do "privado" ou do "social" mostrando-se muito mais capaz de refletir sobre as sociedades contemporâneas (para usar os termos de Habermas) do que ela se mostra, a esse respeito, em $A$ condição humana e em Sobre a revolução.

7 Nota-se que Arendt só é capaz de fazê-lo porque recorta, a favor da sua tese, os textos de Marx, sem levar em consideração, por exemplo, que a atividade do trabalho transforma a natureza e também o próprio homem, que cria um mundo distinto da natureza ao intervir nessa mesma natureza e ao desenvolver as suas capacidades produtivas. Essa transformação não interessa a ela, mas sim a redução do homem a um animal laborans, que parece encontrar mais sustentação em $A$ ideologia alemã do que em $O$ capital. No entanto, não é meu propósito avaliar a pertinência da interpretação que Arendt faz desses textos, mas apenas ressaltar o modo como ela os lê e os questiona a fim de ampliar as atividades humanas para além do suposto confinamento do homem à atividade do labor.

8 O modo como Arendt encaminha o argumento revela forte inspiração kantiana. É curioso, entretanto, que ela não se refira a Kant ao desenvolver esse tópico, autor que lhe embasa em

doispontos, Curitiba, São Carlos, vol. 7, n. 4, p.163-188, setembro, 2010 
tantos outro momentos. Talvez porque, para Kant, essa responsabilidade para com as gerações vindouras esteja intimamente relacionada com a sua filosofia da história, que ela não pode aceitar, obviamente (Cf. KANT, 2008).

9 Nota-se que Arendt, ao acusar a contradição, não leva em consideração (ou não leva seriamente) que o que Marx coloca em primeiro plano é a abolição do trabalho alienado, que aparta o homem de si mesmo e do que ele produz; aquele tipo de trabalho a que Marx e Engels se referem, no Manifesto, como responsável por fazer do trabalhador "um simples acessório da máquina, (...) um soldado da indústria", despojado de sua personalidade e transformado em simples força de trabalho. Este trabalho será abolido quando a racionalidade capitalista for abolida pela colaboração social (e racional) dos indivíduos que terão submetido o processo de produção ao controle comum. No entanto, Arendt não parece interessada nessa parte da teoria do trabalho, mas se concentra na passagem da Ideologia Alemã onde os homens socializados se tornariam pastores, pescadores, críticos, etc., com a intenção clara de defender que os homens não conquistariam sua liberdade e dignidade por terem se apoderado coletivamente da produção social. A origem da contradição é a definição do homem como animal laborans, uma definição que privilegia a necessidade em detrimento da capacidade humana para a comunicação e ação.

10 Além do mais, quando ela se propõe a explicar a ascensão da burguesia ao poder (ARENDT, 2004, II, I) o faz como Marx fez: foi para manter o poderio econômico que a classe burguesa tomou o Estado: as páginas de As origens nas quais ela descreve a emancipação da burguesia e a sua chegada ao poder reproduzem o modelo "estrutura/superestrutura", que condiciona a forma do Estado e a consciência social à estrutura econômica da sociedade.

11 “Marx não glorifica a Comuna de Paris, de 1871, e não queria Lênin conceder todo o poder aos soviets? Mas para Marx, a Comuna não era mais do que 'uma alavanca para arrancar da terra as fundações econômicas (...) do domínio de classe', e que Engels, com correção, identificou com a igualmente transitória ditadura do proletariado"” (ARENDT, 2009, p. 39, nota 39).

12 “A glorificação da violência por Marx continha, portanto a mais específica negação do logos, do discurso, a forma de relacionamento que lhe é diametralmente oposta e, tradicionalmente, a mais humana. A teoria das superestruturas ideológicas de Marx assenta-se, em última instancia, em sua hostilidade antitradicional ao discurso e na glorificação da violência" (ARENDT, 1992, p. 50).

13 Apesar de não se referir nominalmente a Adorno e Horkheimer, há diversas passagens de "Ideologia e terror" e $A$ condição humana nas quais ela parece responder aos autores de $A$ dialética do esclarecimento. Sabemos que Arendt não nutria muita simpatia por Adorno por causa do episódio da publicação das Teses de Benjamin, mas além dessa contenda pessoal, há muitas divergências teóricas que merecem ser investigadas. É bastante provável que o pessimismo "supersticioso" que ela condena em As origens do totalitarismo, bem como a "mensagem" que nos envia o princípio da natalidade, ou ainda a sua posição em relação à reificação (tal como exposta em $A$ condição humana), tenham como pano de fundo um diálogo não revelado com tais autores.

14 Continua ela: "Tais controles políticos parecem funcionar melhor nos chamados 'estados beneficientes' quer chamem a si mesmos de socialistas ou capitalistas. O que protege a liber-

doispontos, Curitiba, São Carlos, vol. 7, n. 4, p.163-188, setembro, 2010 
dade é a divisão entre poder econômico e poder governamental, ou, na linguagem de Marx, o fato de que o estado e sua constituição não são supra-estruturas” (ARENDT, 1973, p. 184).

15 “A grande distinção hoje não é entre países socialistas e capitalistas, mas entre países que respeitam esses direitos [conquistados pelos trabalhadores], como, por exemplo, de um lado, a Suécia, de outros os Estados Unidos, e os que não os respeitam, como, por exemplo, a Espanha de Franco, de um lado, e a Rússia Soviética, de outro. O que fez, então, o socialismo, ou o comunismo, tomados em sua forma pura? Destruiu esta classe também [a dos trabalhadores], suas instituições, sindicatos, partidos trabalhistas e seus direitos" acordo salarial, greves, seguro desemprego, segurança social. Em lugar disso, estes regimes ofereceram a ilusão de que as fábricas eram propriedades das classes dos trabalhadores, que como classe tinha sido a pouco abolida, e a mentira atroz de que não existia mais desemprego, uma mentira baseada em nada mais que a não existência bem real do seguro desemprego. Essencialmente, o socialismo simplesmente continuou, e levou ao extremo, o que o capitalismo começara. Por que deveria ser o remédio?” (ARENDT, 1973, p. 185).

16 Cf. nota 6.

17 Menciono duas das que julgo as mais relevantes: a de J. Habermas e de S. Benhabib. Partindo do conceito de poder comunicativo, que ele credita a Arendt, Habermas defende, em Direito e democracia, que o direito seja considerado o "médium através do qual o poder comunicativo se transforma em poder administrativo" (HABERMAS, 2003, vol. I, p. 190). Para ele, Arendt estava certa ao afirmar que nenhum poder político "pode ampliar as fontes do seu poder ao seu bel-prazer" (HABERMAS, 2003, p. 189) e que "o exercício da autonomia política significa a formação discursiva da vontade comum” (Idem, op. cit., 190). Mas, como ela não explica como é que o conceito do político estende-se "também ao emprego do poder administrativo e à concorrência pelo acesso ao poder político", é preciso continuar o trabalho de Arendt e esclarecer algo que ela introduziu "dogmaticamente" (HABERMAS, 2003, p.186). Não vou retomar todo o argumento de Habermas aqui, o que será assunto para outro texto, mas menciono apenas o seu ponto de partida - o conceito arendtiano de poder comunicativo - e o de chegada - a conclusão de que o direito deve ser o médium entre os poderes comunicativo e administrativo. É também em diálogo crítico com a concepção arendtiana de espaço publico que S. Benhabib formula a sua própria. Como Habermas, ela reconhece a extrema importância de Arendt por abrir caminho para um conceito não substantivo, mas procedimental, de espaço público, onde "o que importa não é tanto do que trata o discurso público, mas sim a maneira pela qual ele se produz" e também, em certos aspectos, a sua superioridade em relação à concepção liberal de espaço público, justamente por enfatizar a participação e a comunicação (BENHABIB, 2006, p.112). Pretendo, em outra ocasião, investigar a presença efetiva desse conceito arendtiano nas teorias de Habermas e Benhabib, bem como os ajustes que ambos fazem nele a fim de torná-lo mais capaz de responder às questões contemporâneas.

\section{Referências bibliográficas}
ADORNO, T. \& HORKHEIMER, M. 1985. Dialética do esclarecimento. Rio de Janeiro: Jorge Zaar Editor. 
ARENDT, H. 2010. A condição humana. Tradução Roberto Raposo. Revisão e apresentação Adriano Correia. São Paulo: Forense Universitária.

ARENDT, H. 1992. Entre o passado e o futuro. São Paulo: Editora Perspectiva.

ARENDT, H. 2004. As origens do totalitarismo. São Paulo: Companhia das Letras.

ARENDT, H. 1973. Crises da república. São Paulo: Editora Perspectiva. ARENDT, H. 1990. Sobre a revolução. São Paulo: Editora Ática.

ARENDT, H. 2007. O que é política? Rio de Janeiro: Bertrand Brasil. ARENDT, H. 2009. Sobre a violência. Tradução de André Duarte. Rio de Janeiro: Civilização Brasileira.

BENHABIB, S. 2006. El ser e el outro em la ética contemporânea [Situating the self]. Barcelona: Editorial Egisa.

BENHABIB, S. 2000. The Reluctant Modernism of H. Arendt. Oxford: Rowman \& Littlefield Publishers.

DUARTE, A. 2000. O pensamento à sombra da ruptura: política e filosofia em H. Arendt. São Paulo: Paz e Terra.

FRATESCHI,Y. 2007. "Participação e liberdade política em Hannah Arendt" Cadernos de Filosofia Alemã, São Paulo, pp. 83-100, julho a dezembro de 2007.

GORZ A. 2003. As metamorfoses do trabalho. São Paulo: Annablume.

HABERMAS, J. 1977. "Hannah Arendt's Communications Concept of Power”. Social Research, pp. 3-24.

HABERMAS, J. 2003. Direito e democracia. Rio de Janeiro: Tempo Brasileiro.

KANT, I. 2008 "Idéia de uma história universal de um ponto de vista cosmopolita". In KANT, I. A paz perpétua e outros opúsculos. Lisboa: Edições 70 . 
188

MARX, K \& ENGELS, F. 2002. A ideologia alemã. São Paulo: Martins Fontes.

YOUNG-BRUEHL, E. 1997. Por amor ao mundo: vida e obra de Hannah Arendt. Rio de Janeiro: Relume Dumará.

VILLA, D. 1996. Arendt and Heidegger. Princeton: Princeton University Press. 